\title{
Soybean seed protein, oil, fatty acids, and mineral composition as influenced by soybean-corn rotation
}

\author{
Nacer Bellaloui ${ }^{1 *}$, H. Arnold Bruns ${ }^{2}$, Anne. M. Gillen ${ }^{1}$, Hamed K. Abbas ${ }^{1}$, Robert M. Zablotowicz ${ }^{2}$, \\ Alemu Mengistu ${ }^{3}$, Robert L. Paris ${ }^{4}$ \\ ${ }^{1}$ Crop Genetics Research Unit, USDA-ARS, Stoneville, USA; ${ }^{*}$ Corresponding Author: nacer.bellaloui@ars.usda.gov \\ ${ }^{2}$ Crop Production Systems Research Unit, USDA-ARS, Stoneville, USA \\ ${ }^{3}$ Crop Genetics Research Unit, USDA-ARS, Jackson, USA \\ ${ }^{4}$ The American Chestnut Foundation, Beckley, USA
}

Received 6 July 2010; revised 20 August 2010; accepted 24 August 2010.

\begin{abstract}
Effects of crop rotation on soybean (Glycine $\max (L)$ Merr.) seed composition have not been well investigated. Therefore, the objective of this study was to investigate the effects of soybean-corn (Zea mays L.) rotations on seed protein, oil, and fatty acids composition on soybean. Soybeans were grown at Stoneville, MS, from 2005 to 2008 in five different scheduled cropping sequences. In 2007, following three years of rotation with corn, seed oleic acid percentage was significantly higher in any crop rotation than continuous soybean. The increase of oleic fatty acid ranged from 61 to $68 \%$ in 2007 , and from 27 to $51 \%$ in 2008, depending on the rotation. The increase of oleic acid was accompanied by significant increases in seed concentrations of phosphorus (P), iron (Fe), and boron (B). In 2007, the increase of $P$ ranged from 60 to $75 \%$, Fe from 70 to $72 \%$, and B from 34 to $69 \%$. In 2008, the increase of $P$ ranged from 82 to $106 \%$, Fe from 32 to $84 \%$, and B from 62 to $77 \%$. Continuous soybean had higher linoleic:oleic ratio and linoleic: palmitic + stearic + oleic ratio, indicating that relative quantity of linoleic acid decreased in rotated crops. The total production of protein, oil, stearic and oleic fatty acids was the lowest in continuous soybean. The total production of palmitic acid was inconsistent across years. The results show that soybeancorn rotation affects seed composition by consistently increasing seed oleic fatty acid, $\mathrm{P}, \mathrm{Fe}$, and $B$ concentrations. Higher oleic acid, unsa-
\end{abstract}

Mention of trade names or commercial products in this publication is solely for the purpose of providing specific information and does not imply recommendation or endorsement by the U.S. Department of Agriculture. turated fatty acid, is desirable for oil stability and long-shelf storage. The mechanisms of how these nutrients are involved are not yet understood.

Keywords: Fatty Acids; Mineral Nutrients; Oil; Protein; Seed Composition; Soybean-Corn Rotation

\section{INTRODUCTION}

Soybean is a major source of high quality protein and oil [1], and soybean seed quality is often determined by seed protein, oil, fatty acid, and mineral content. Therefore, improving soybean seed quality is key to improving human and animal nutrition. Soybean seed protein concentration ranges from 341 to $568 \mathrm{~g} \mathrm{~kg}^{-1}$ of total seed weight, with a mean of $421 \mathrm{~g} \mathrm{~kg}^{-1}$. Oil concentration ranges from $83 \mathrm{~g} \mathrm{~kg}^{-1}$ to $279 \mathrm{~g} \mathrm{~kg}^{-1}$ with a mean of $195 \mathrm{~g}$ $\mathrm{kg}^{-1}$ [2]. Saturated fatty acids in soybean oil range from $100 \mathrm{~g} \mathrm{~kg}^{-1}$ to $120 \mathrm{~g} \mathrm{~kg}^{-1}$ for palmitic acid, and from $22 \mathrm{~g}$ $\mathrm{kg}^{-1}$ to $72 \mathrm{~g} \mathrm{~kg}^{-1}$ for stearic acid [3]. The mean concentration of unsaturated fatty acids is $240 \mathrm{~g} \mathrm{~kg}^{-1}$ for oleic acid, $540 \mathrm{~g} \mathrm{~kg}^{-1}$ for linoleic acid, and $80 \mathrm{~g} \mathrm{~kg}^{-1}$ for linolenic acid [4]. There was a negative relationship between elevated protein and oil concentration in soybean cultivars and yield [5], and a negative correlation between protein and oil [6]. Previous research has shown significant effects of production practices in soybean on protein and oil concentration of a soybean seed [7].

Crop rotation has been shown to improve soil structure [8], increase crop water use efficiency $[9,10]$, increase soil organic matter [11], and improve nutrient use efficiency [12]. Studies showed that a two-year cornsoybean rotation increased both corn [12] and soybean yields [13], and increased soybean and grain sorghum (Sorghum bicolor L. Moench) yields in a soybean-sorghum rotation $[9,14]$. Both corn grain and soybean seed 
yields were greater in rotation than continuous cropping (7.10 $\mathrm{Mg} \mathrm{ha}^{-1}$ vs. $5.83 \mathrm{Mg} \mathrm{ha}^{-1}$ ) and soybean $(2.57 \mathrm{Mg}$ $\mathrm{ha}^{-1}$ vs. $2.35 \mathrm{Mg} \mathrm{ha}^{-1}$ ) [15]. However, crop rotation and its effects on soybean seed composition have yet to be thoroughly investigated.

It was shown that soybean seed protein concentration decreased from $357 \mathrm{mg} \mathrm{kg}^{-1}$ in first-year soybean following five consecutive years of corn to $351 \mathrm{mg} \mathrm{kg}^{-1}$ in fifth-year soybean following five consecutive years of corn [7]. Soybean oil concentration increased as consecutive years of soybean production increased. It was found that higher protein and oleic fatty acid percentages were accompanied with higher soil $\mathrm{B}$, indicating that maintaining optimum nutrient concentrations in soil may result in higher seed protein and oleic acid [16]. A positive correlation of $\mathrm{B}$ with protein and oleic acid was also found [16], suggesting an indirect role of B with seed composition. This observation was supported by previous research when foliar B application increased soybean seed protein and oleic acid concentrations [17].

The objective of this research was to investigate how seed protein, oil, and fatty acid concentrations are influenced by soybean-corn rotation sequences compared to continuous soybean grown under Early Soybean Production Systems (ESPS). Since recent mineral nutrient levels in seed were observed to influence seed composition $[16,17]$, seed P, Fe, and B were also determined.

\section{MATERIALS AND METHODS}

\subsection{Growth Conditions and Field Management}

The research was conducted at Mississippi State University's Delta Branch Experiment Station at Stoneville, MS from 2005 to 2008. Soil at the experimental site was analyzed in 2005, and was a Dundee silty clay (fine-silty, mixed thermic Typic Dystrochrepts) comprised of 16\% sand, $52 \%$ silt, $32 \%$ clay, and $1.76 \%$ organic matter (OM). The rotation scheduled sequences were: 1) continuous soybean, SSSS; 2) 1 year corn followed by 1 year soybean, CSCS; 3) 1 year soybean followed by 1 year corn, SCSC; 4) 2 years of corn followed by 2 years of soybean, CCSS; 5) 2 years of soybean followed by 1 year corn followed by 1 year soybean, SSCS. The soil mineral concentrations [ ] in 2005 were $380 \mathrm{mg} \mathrm{kg}^{-1} \mathrm{P}$, $1.76 \% \mathrm{Fe}$, and $1.13 \mathrm{mg} \mathrm{kg}^{-1} \mathrm{~B}$. Soil analysis in 2008 indicated that $[\mathrm{P}]$ was $414 \mathrm{mg} \mathrm{kg}^{-1}$ in SSSS, $572 \mathrm{mg} \mathrm{kg}^{-1}$ in CSCS, $497 \mathrm{mg} \mathrm{kg}^{-1} \mathrm{CCSS}$, and $442 \mathrm{mg} \mathrm{kg}^{-1}$ in SSCS; [Fe] was $1.67 \%$ in SSSS, $1.8 \%$ in CSCS, $1.81 \%$ in CCSS, and $1.86 \%$ in SSCS. [B] was $1.36 \mathrm{mg} \mathrm{kg}^{-1}$ in SSSS, 2.86 $\mathrm{mg} \mathrm{kg}^{-1}$ in CSCS, $2.51 \mathrm{mg} \mathrm{kg}^{-1}$ in CCSS, and $2.33 \mathrm{mg}$ $\mathrm{kg}^{-1}$ in SSCS. Soil analysis in 2008 indicated that soil organic matter was $2.3 \%$ in SSSS, $1.8 \%$ in CSCS, $2.6 \%$ in SCSC, and $2.1 \%$ in SSCS.

Individual experimental units were eight $76 \mathrm{~cm}$ rows 9 $\mathrm{m}$ long. The land was prepared each season by forming $40 \mathrm{~cm}$ high ridges in late winter for planting. Supplemental $\mathrm{N}$ as urea: $\mathrm{NH}_{4} \mathrm{NO}_{3}$ liquid was applied to the corn each year to a yield goal of $8.5 \mathrm{Mg} \mathrm{ha}^{-1}$. The experiment was furrow irrigated approximately every 10 days beginning at the reproductive growth stages of the corn. Both corn and soybean were planted on 7 April, 2005, 12 April, 2006, 11 April, 2007, and 14 April, 2008. Seeding rate for soybean was 30 seed $\mathrm{m}^{-2}$. Weed control in both crops was achieved by applying glyphosate $[N$-(phosphorrnomethyl)glycine] post emergence at a rate of 0.8 $\mathrm{kg}$ ae $\mathrm{ha}^{-1}$. Beginning in 2006 after the first year of the rotations, soybean seed were collected annually and analyzed for seed protein, oil, fatty acids, [P], [Fe], and [B].

\subsection{Soil Sampling and Analyses}

Soil samples taken on 0.203 ha grid across the field were collected at the beginning of the experiment in 2005 and at the end in 2008 to determine the soil texture and initial and final $[\mathrm{P}],[\mathrm{Fe}]$, and [B]. Composite samples were also taken from each experimental unit to monitor any changes in soil chemical and/or physical properties. The soil samples were analyzed at The University of Georgia's Soil, Plant, and Water Laboratory, Athens, GA, to determine soil structure, texture, and organic matter and (OM).

\subsection{Seed Mineral Analyses}

\subsubsection{Boron Measurement}

Boron concentration was determined in matured seed with the Azomethine-H method [18]. Calcium carbonate powder was added to $1.0 \mathrm{~g}$ seed samples before ashing at $500 \mathrm{C}$ for 8 hours to prevent losses of volatile B compounds. After ashing, samples were extracted with $20 \mathrm{ml}$ of $2 \mathrm{M} \mathrm{HCl}$ at $90^{\circ} \mathrm{C}$ for $10 \mathrm{~min}$, filtered and transferred to plastic vials. Then, $2 \mathrm{ml}$ of the solution was added to 4 $\mathrm{ml}$ of buffer solution (containing 25\% ammonium acetate, $1.5 \%$ EDTA, and $12.5 \%$ acetic acid) and $4 \mathrm{ml}$ of freshly prepared azomethine-H solution $(0.45 \%$ azomethine-H and $1 \%$ of ascorbic acid) [19]. The color was left to develop for at least $45 \mathrm{~min}$ at ambient temperature, and [B] determined using a Beckman Coulter DU 800 spectrophotometer (Fullerton, California, U.S.A.) at $420 \mathrm{~nm}$.

\subsubsection{Iron Measurement}

Iron concentration in matured seed was measured after acid wet digestion, extraction, and reaction of the 
reduced ferrous Fe with 1, 10-phenanthroline [20,21]. A sample of $2 \mathrm{~g}$ of dried ground seed were digested in nitric acid $\left(70 \% \mathrm{~m} / \mathrm{m} \mathrm{HNO}_{3}\right)$. The acids were removed by volatilization and the soluble constituents dissolved in 2 $\mathrm{M} \mathrm{HCl}$. Iron standard solutions were prepared in $0.4 \mathrm{M}$ $\mathrm{HCl}$, ranging from 0.0 to $4 \mu \mathrm{g} \mathrm{ml}^{-1} \mathrm{Fe}$. Phenanthroline solution of $0.25 \% \mathrm{~m} / \mathrm{v}$ was prepared in $25 \% \mathrm{v} / \mathrm{v}$ ethanol. The quinol solution $(1 \% \mathrm{~m} / \mathrm{v})$ reagent was prepared on the day of use. Approximately $4 \mathrm{ml}$ of aliquot was pipetted into $25 \mathrm{ml}$ volumetric flask. The aliquot was diluted to $5 \mathrm{ml}$ using $0.4 \mathrm{M} \mathrm{HCl}$. Quinol solution $(1 \mathrm{ml})$ was added and mixed. Then $3 \mathrm{ml}$ of phenanthroline solution and $5 \mathrm{ml}$ of tri-sodium citrate solution $(8 \% \mathrm{~m} / \mathrm{v})$ were added. The mixture solution containing the aliquot, $\mathrm{HCl}$, phenanthroline, tri-sodium citrate, was diluted to $25 \mathrm{ml}$ and stood for $4 \mathrm{~h}$ Absorbance of the samples was read at 510 nm using a Beckman Coulter DU 800 spectrophotometer.

\subsubsection{Phosphorus Measurement}

Phosphorus concentration in matured seed was measured spectrophotometrically as the yellow phospho-vanado-molybdate complex [22,23]. A dry $2 \mathrm{~g}$ sample of seed was ashed to completely destroy organic matter. After ashing, $10 \mathrm{ml}$ of $6 \mathrm{M} \mathrm{HCl}$ was added and the sample placed in water bath at $70^{\circ} \mathrm{C}$ to evaporate the solution to dryness. After drying, the samples were kept under heat, $2 \mathrm{ml}$ of $36 \% \mathrm{~m} / \mathrm{m} \mathrm{HCl}$ was added, and gently boiled. Later, $10 \mathrm{ml}$ of water was added and the solution was carefully boiled for about $1 \mathrm{~min}$.). The aliquot was transferred to a $50 \mathrm{ml}$ volumetric flask and diluted to volume. The sample solution was then filtered after the first $2 \mathrm{ml}$ were discarded and the remainder was kept for $\mathrm{P}$ analysis. $5 \mathrm{ml}$ of the sample was taken. $5 \mathrm{ml}$ of $5 \mathrm{M}$ $\mathrm{HCl}$ and $5 \mathrm{ml}$ of ammonium molybdate-ammonium metavanadate (a solution of ammonium molybdate, $\left(\mathrm{NH}_{4}\right)_{2} \mathrm{MoO}_{4}(25 \mathrm{~g} / 500 \mathrm{ml}$ water $)$, and ammonium metavanadate, $\left.\mathrm{NH}_{4} \mathrm{VO}_{3}\right)(1.25 \mathrm{~g} / 500 \mathrm{ml}$ water$)$ reagent were added, diluted to $50 \mathrm{ml}$, and allowed to stand for $30 \mathrm{~min}$ at ambient temperature before measurement. The concentration of $\mathrm{P}$ was determined using a Beckman Coulter DU 800 spectrophotometer at $400 \mathrm{~nm}$. Phosphorus standard solution ( $0-50 \mu \mathrm{g} / \mathrm{ml}$ of phosphorus) was made using dihydrogen orthophosphate dissolved in both water and $36 \% \mathrm{~m} / \mathrm{m} \mathrm{HCl}$.

\subsubsection{Seed Protein, Oil, Fatty Acid Analyses}

Seeds from each soybean plot were sampled and analyzed for protein, oil, and fatty acids beginning in 2005 through 2008 using a near-infrared (NIR) reflectance diode array feed analyzer (Perten, Springfield, IL,
U.S.A.) [24,25]. Calibrations were developed by Perten using Thermo Galactic Grams PLS IQ. The calibration curve has been regularly updated for unique samples according to AOAC methods [26,27].

\subsection{Experimental Design and Statistical Analyses}

The experimental design was a randomized complete block replicated four times. Rotation sequences were assigned at random at the initiation of the experiment and remained in place during its duration. To compare individual treatments, data were analyzed using PROC GLM [28]. Means were separated by Fisher's least significant difference (LSD) test at the 5\% level of probability. To compare across rotations with continuous soybean, 'contrast' option for planned contrasts of SAS (SAS Institute, Cary, NC) [28] was used. Because of the design of the experiment and since the objective of the experiment was to compare soybean-corn rotation with continuous soybean in each year, data were analyzed separately in each year.

\section{RESULTS}

\subsection{Seed Yield and Composition}

Yield increased in all soybean-corn rotation sequences compared to continuous soybean (Table 1). These increases ranged from $10 \%$ to $13 \%$ in $2007,19 \%$ to $22 \%$ in 2008 (Table 1). In 2007, seed protein and oleic acid percentages were higher in all soybean-corn rotation compared to continuous soybean (Table 1). In 2008, oleic fatty acid was also higher in any crop rotation compared to continuous soybean (Table 1). The increase of oleic fatty acid ranged from 61 to $68 \%$ in 2007, and from 27 to $51 \%$ in 2008 , depending on the rotation. Protein percentage increase ranged from 3.6 to $7.8 \%$ in 2007 , and from 0.11 to $4.5 \%$ in 2008 , depending on the rotation (Table 1). The opposite trend was observed for oil and linoleic acid, confirming the inverse relationship between protein and oil percentages, and between oleic and linoleic acids (Table 1). Compared with soybeancorn rotation, continuous soybean had higher linoleic: oleic ratio, and it is evident, especially in 2007 and 2008 (Table 1).

Total production of protein and oleic acid on a $\mathrm{kg} \mathrm{ha}^{-1}$ were higher in any soybean-corn rotation regardless soybean-corn rotation sequence, and lowest in continuous soybean in both 2007 and 2008 (Table 2). For example, in 2007 , following three years of rotation with corn, total seed constituents were higher, $17-19 \%$ for protein, $4-8 \%$ 
for oil, $14-17 \%$ for palmitic, $9-15$ for stearic, $78-90 \%$ for oleic, and $2 \%$ for linoleic acids compared to seed from continuous soybean plots (Table 2). Protein, oil, and linoleic acid production, on a $\mathrm{kg} \mathrm{ha}^{-1}$ was consistently greater in any rotation compared to monoculture soybean (Table 2). Compared with soybean-corn rotation, continuous soybean had higher linoleic: palmitic + stearic + oleic ratio, especially in 2007 and 2008 (Table 2).

Planned contrast analysis confirmed that oleic acid was consistently significantly different (lowest in continuous soybean) between continuous soybean vs. all soybean-corn rotations in 2007 and 2008 (Table 3).

Table 1. Mean values of protein, oil, fatty acid percentages (\%), and yield $\left(\mathrm{kg} \mathrm{ha}^{-1}\right)$ as affected by scheduled rotation.

\begin{tabular}{|c|c|c|c|c|c|c|c|}
\hline Year & Rotation & $\begin{array}{c}\text { Yield } \\
\left(\mathrm{kg} \mathrm{ha}^{-1}\right)\end{array}$ & Protein $(\%)$ & Oil (\%) & Oleic (\%) & Linoleic (\%) & $\begin{array}{c}\text { Ratio } \\
\text { Linoleic/Oleic }\end{array}$ \\
\hline \multirow[t]{3}{*}{2006} & SSSS & 4549 a & $39.78 \mathrm{~b}$ & $21.08 \mathrm{a}$ & $22.63 \mathrm{a}$ & $54.07 \mathrm{a}$ & 2.39 \\
\hline & CSCS & $4682 \mathrm{a}$ & $39.70 \mathrm{~b}$ & $21.02 \mathrm{a}$ & $23.13 \mathrm{a}$ & $53.85 \mathrm{a}$ & 2.33 \\
\hline & SSSS & $3468 \mathrm{~b}$ & $43.10 \mathrm{a}$ & $23.10 \mathrm{a}$ & $18.23 \mathrm{~b}$ & $63.83 \mathrm{a}$ & 3.50 \\
\hline \multirow[t]{3}{*}{2007} & SCSC & $3824 \mathrm{~b}$ & $46.45 \mathrm{a}$ & $21.80 \mathrm{a}$ & $29.38 \mathrm{a}$ & $59.00 \mathrm{~b}$ & 2.00 \\
\hline & $\mathrm{CCSC}$ & $3934 \mathrm{~b}$ & $44.66 \mathrm{~b}$ & 21.99 a & $30.69 \mathrm{a}$ & $56.15 \mathrm{c}$ & 1.83 \\
\hline & SSSS & $4122 \mathrm{a}$ & $44.58 \mathrm{~b}$ & $21.83 \mathrm{a}$ & $20 \mathrm{c}$ & $61.18 \mathrm{ab}$ & 3.06 \\
\hline \multirow[t]{3}{*}{2008} & CSCS & 5024 a & $46.58 \mathrm{a}$ & $21.85 \mathrm{ab}$ & $30.22 \mathrm{a}$ & $63.13 \mathrm{a}$ & 2.09 \\
\hline & CCSS & 4903 a & $44.63 \mathrm{~b}$ & $22.18 \mathrm{a}$ & $29.85 \mathrm{a}$ & $59.43 \mathrm{~b}$ & 1.99 \\
\hline & SSCS & 4893 a & $44.65 \mathrm{~b}$ & $21.63 \mathrm{~b}$ & $25.43 \mathrm{~b}$ & $61.18 \mathrm{ab}$ & 2.40 \\
\hline
\end{tabular}

Notes: Means within a column in a given year followed by the same letter are not significantly different at $P \leq 5 \%$. Four replicates were used. Scheduled rotations were: SSSS = continuous soybean, CSCS $=1$ year corn followed by 1 year soybean followed by 1 year corn followed by 1 year corn, CCSS $=2$ years of corn followed by 2 years of soybean, SSCS $=2$ years of soybean followed by 1 year corn followed by 1 year soybean.

Table 2. Mean values of total production of protein, oil, fatty acids as affected by scheduled rotation.

\begin{tabular}{|c|c|c|c|c|c|c|c|c|}
\hline Year & Rotation & $\begin{array}{l}\text { Protein } \\
\left(\mathrm{kg} \mathrm{ha}^{-1}\right)\end{array}$ & $\begin{array}{c}\text { Oil } \\
\left(\mathrm{kg} \mathrm{ha}^{-1}\right)\end{array}$ & $\begin{array}{l}\text { Palmitic } \\
\left(\mathrm{kg} \mathrm{ha}^{-1}\right)\end{array}$ & $\begin{array}{c}\text { Stearic } \\
\left(\mathrm{kg} \mathrm{ha}^{-1}\right)\end{array}$ & $\begin{array}{c}\text { Oleic } \\
\left(\mathrm{kg} \mathrm{ha}^{-1}\right)\end{array}$ & $\begin{array}{l}\text { Linoleic } \\
\left(\mathrm{kg} \mathrm{ha}^{-1}\right)\end{array}$ & $\begin{array}{l}\text { Ratio } \\
\text { C/Lino }\end{array}$ \\
\hline \multirow{3}{*}{2006} & SSSS & $1810 \mathrm{a}$ & 959 a & $476 \mathrm{a}$ & $221 \mathrm{a}$ & $1030 \mathrm{a}$ & $2460 \mathrm{a}$ & 1.4 \\
\hline & & & & & & & & \\
\hline & $\mathrm{CSCS}$ & $1860 \mathrm{a}$ & $984 \mathrm{a}$ & $476 \mathrm{a}$ & $225 \mathrm{a}$ & $1085 \mathrm{a}$ & $2520 \mathrm{a}$ & 1.4 \\
\hline \multirow{3}{*}{2007} & SSSS & $1495 \mathrm{~b}$ & $802 \mathrm{a}$ & $333 \mathrm{~b}$ & $117 \mathrm{~b}$ & $632 \mathrm{~b}$ & $2214 \mathrm{a}$ & 2.0 \\
\hline & SCSC & $\begin{array}{l}1774 \mathrm{a} \\
(19 \%)\end{array}$ & $\begin{array}{c}833 \mathrm{a} \\
(3.9 \%)\end{array}$ & $\begin{array}{l}380 \mathrm{a} \\
(14 \%)\end{array}$ & $\begin{array}{c}128 \mathrm{ab} \\
(9 \%)\end{array}$ & $\begin{array}{l}1125 \mathrm{a} \\
(78 \%)\end{array}$ & $\begin{array}{c}2258 \mathrm{a} \\
(2 \%)\end{array}$ & 1.4 \\
\hline & $\mathrm{CCSC}$ & $\begin{array}{l}1756 \mathrm{a} \\
(17 \%)\end{array}$ & $\begin{array}{c}864 \mathrm{a} \\
(7.7 \%)\end{array}$ & $\begin{array}{l}391 \mathrm{a} \\
(17 \%)\end{array}$ & $\begin{array}{c}134 \mathrm{a} \\
(14.5 \%)\end{array}$ & $\begin{array}{l}1202 \mathrm{a} \\
(90 \%)\end{array}$ & $\begin{array}{c}2209 \mathrm{a} \\
(-0.2 \%)\end{array}$ & 1.3 \\
\hline \multirow{4}{*}{2008} & SSSS & $1839 \mathrm{~b}$ & $899 \mathrm{~b}$ & $470 \mathrm{a}$ & $141 \mathrm{~b}$ & $823 \mathrm{c}$ & $2515 \mathrm{~b}$ & 1.8 \\
\hline & CSCS & $\begin{array}{l}2338 \mathrm{a} \\
(27 \%)\end{array}$ & $\begin{array}{l}1099 \mathrm{a} \\
(22 \%)\end{array}$ & $\begin{array}{l}549 \mathrm{a} \\
(17 \%)\end{array}$ & $\begin{array}{l}176 \mathrm{a} \\
(15 \%)\end{array}$ & $\begin{array}{l}1521 \mathrm{a} \\
(85 \%)\end{array}$ & $\begin{array}{l}3173 \mathrm{a} \\
(16 \%)\end{array}$ & 1.4 \\
\hline & CCSS & $\begin{array}{l}2189 \mathrm{a} \\
(19 \%)\end{array}$ & $\begin{array}{l}1087 \mathrm{a} \\
21 \%)\end{array}$ & $\begin{array}{l}561 \mathrm{a} \\
(19 \%)\end{array}$ & $\begin{array}{l}168 \mathrm{ab} \\
(19 \%)\end{array}$ & $\begin{array}{c}1474 \mathrm{ab} \\
(79 \%)\end{array}$ & $\begin{array}{c}2914 \mathrm{ab} \\
(16 \%)\end{array}$ & 1.3 \\
\hline & SSCS & $\begin{array}{l}2185 \mathrm{a} \\
(19 \%)\end{array}$ & $\begin{array}{c}1058 \mathrm{ab} \\
(18 \%)\end{array}$ & $\begin{array}{l}540 \mathrm{a} \\
(15 \%)\end{array}$ & $\begin{array}{l}170 \mathrm{a} \\
(21 \%)\end{array}$ & $\begin{array}{l}1243 \mathrm{~b} \\
(51 \%)\end{array}$ & $\begin{array}{l}2993 \mathrm{a} \\
(19 \%)\end{array}$ & 1.5 \\
\hline
\end{tabular}

Notes: Means within a column in a given year followed by the same letter are not significantly different at $P \leq 5 \%$. Four replicates were used. Scheduled rotations were: SSSS = continuous soybean, CSCS $=1$ year corn followed by 1 year soybean followed by 1 year corn followed by 1 year corn, CCSS $=2$ years of corn followed by 2 years of soybean, SSCS $=2$ years of soybean followed by 1 year corn followed by 1 year soybean. Values in parenthesis indicate percentage increase compared with the continuous soybean (SSSS). C/Lino is a ratio between linoleic acid and combined fatty acids (palmitic + steraic + oleic). 
Table 3. Contrasts comparing pooled data across all soybean-corn rotations vs. continuous soybean to investigate the effects of rotation on soybean seed composition, mineral nutrients, and yield.

\begin{tabular}{|c|c|c|c|c|}
\hline variable & contrast (mean) & difference & $\mathrm{T}$ & $\operatorname{Pr}>\mathrm{T}$ \\
\hline \multicolumn{5}{|l|}{2007} \\
\hline Yield $\left(\mathrm{kg} \mathrm{ha}^{-1}\right)$ & Rotation (3879) vs. continuous soybean (3478) & 411 & 2.34 & 0.0356 \\
\hline Protein $(\%)$ & Rotation (45.56) vs. continuous soybean (43.10) & 2.46 & 6.67 & $<.0001$ \\
\hline Oil (\%) & Rotation (21.89) vs. continuous soybean (23.10) & -1.21 & -4.43 & 0.0013 \\
\hline Palmitic acid (\%) & Rotation (9.93) vs. continuous soybean $(9.63)$ & 0.31 & 1.01 & 0.3294 \\
\hline Stearic acid $(\%)$ & Rotation (3.381) vs. continuous soybean (3.375) & 0.01 & 0.15 & 0.8873 \\
\hline Oleic acid (\%) & Rotation (30.03) vs. continuous soybean (18.26) & 11.81 & 6.17 & $<.0001$ \\
\hline Linoleic acid (\%) & Rotation (57.58) vs. continuous soybean (63.83) & -6.25 & -6.78 & $<.0001$ \\
\hline Linolenic acid (\%) & Rotation (5.79) vs. continuous soybean (5.18) & 0.61 & 1.58 & 0.1384 \\
\hline $\mathrm{B}\left(\mathrm{mg} \mathrm{kg}^{-1}\right)$ & Rotation (67.94) vs. continuous soybean (44.50) & 23.44 & 8.66 & $<.0001$ \\
\hline $\mathrm{Fe}\left(\mathrm{mg} \mathrm{kg}^{-1}\right)$ & Rotation $(92.25)$ vs. continuous soybean $(54.00)$ & 38.25 & 5.87 & 0.0001 \\
\hline $\mathrm{P}\left(\mathrm{g} \mathrm{kg}^{-1}\right)$ & Rotation (4.27) vs. continuous soybean (2.55) & 1.72 & 6.01 & $<.0001$ \\
\hline \multicolumn{5}{|l|}{2008} \\
\hline Yield (kg ha-1) & Rotation (4940) vs. continuous soybean (4122) & 818 & 3.04 & 0.0140 \\
\hline Protein $(\%)$ & Rotation (45.56) vs. continuous soybean (43.1) & 0.71 & 1.88 & 0.0927 \\
\hline Oil (\%) & Rotation (21.88) vs. continuous soybean (21.83) & 0.06 & 0.30 & 0.7686 \\
\hline Palmitic acid (\%) & Rotation (11.12) vs. continuous soybean (11.40) & -0.28 & -0.97 & 0.3526 \\
\hline Stearic acid $(\%)$ & Rotation (3.47) vs. continuous soybean (3.43) & 0.04 & 1.00 & 0.3370 \\
\hline Oleic acid (\%) & Rotation (28.50) vs. continuous soybean (20.00) & 8.50 & 8.77 & $<.0001$ \\
\hline Linoleic acid (\%) & Rotation (61.24) vs. continuous soybean (61.18) & 0.07 & 0.05 & 0.9601 \\
\hline Linolenic acid (\%) & Rotation (5.27) vs. continuous soybean (5.03) & 0.24 & 0.75 & 0.4662 \\
\hline $\mathrm{B}\left(\mathrm{mg} \mathrm{kg}^{-1}\right)$ & Rotation (69.83) vs. continuous soybean (41.25) & 28.58 & 8.84 & $<.0001$ \\
\hline $\mathrm{Fe}\left(\mathrm{mg} \mathrm{kg}^{-1}\right)$ & Rotation (86.92) vs. continuous soybean $(54.00)$ & 32.92 & 5.19 & 0.0006 \\
\hline $\mathrm{P}\left(\mathrm{g} \mathrm{kg}^{-1}\right)$ & Rotation (5.22) vs. continuous soybean (2.73) & 2.50 & 7.53 & $<.0001$ \\
\hline
\end{tabular}

Notes: Mean = mean value for data pooled across soybean-corn rotation treatments or mean for the continuous soybean treatment. Difference $=$ difference between means for treatments in the contrast.

\subsection{Seed Mineral Concentrations}

Seed $[\mathrm{Fe}],[\mathrm{P}]$, and $[\mathrm{B}]$ were all consistently higher in all soybean-corn rotations than in continuous soybean Table 4, beginning second year of rotation. In 2007, the increase in P ranged from 60 to $75 \%, \mathrm{Fe}$ from 70 to $72 \%$, and B from 34 to $69 \%$. In 2008, the increase of P ranged from 82 to $106 \%, \mathrm{Fe}$ from 32 to $84 \%$, and B from 62 to $77 \%$. Significant differences in seed P, Fe, and B concentrations between rotation and continuous soybean were shown in the second year, unlike in seed composition constituents, the rotation showed its effect in the third year Tables 2, 4. There were no significant differences between rotations for $\mathrm{P}$ and $\mathrm{Fe}$ in each year, except for B in 2007 where soybean after two years of corn (CCSC) showed the highest B concentrations Table 4.

\section{DICUSSION}

The higher seed yield in all soybean-corn rotation sequences compared to continuous soybean are similar to those reported in previous studies $[9,13,14]$. The higher seed protein percentage in 2007 and oleic acid percentage in 2007 and 2008 in all soybean-corn rotation com- pared to continuous soybean may be due to the indirect effect of soil nutrients improvement due to soybean-corn rotation. Soil analysis in 2008 indicated that $\mathrm{P}, \mathrm{Fe}$, and B concentrations in any rotation were higher compared with continuous soybean. These differences in soil nutrients between rotation and continuous soybean could indirectly affect seed composition constituents. For example, it was found that B concentration in soil and seed affected seed protein and oleic fatty acid percentage [16], and application of foliar B increased protein and oleic fatty acids and decreased oil and linolenic fatty acid [17]. The opposite trend between protein and oil, and between oleic and linolenic has been previously observed [5,6,17], indicating that the inverse relationships between these constituents still remain a challenge for soybean breeders. The higher ratio between linoleic and oleic acids Table 1, and between linoleic acid and (palmitic + stearic + oleic) Table 2 in continuous soybean indicated a relative quantity decrease in linoleic acid in rotated crops. The consistent increase in total protein, oil, and linoleic acid production on a $\mathrm{kg} \mathrm{ha}^{-1}$ in any rotation compared to monoculture soybean was most likely due to the overall increase in yield in all rotations. This indicates that rota- 
Table 4. Mean values of seed phosphorus (P), iron (Fe), and boron (B) concentrations in scheduled soybean-corn rotation compared with continuous soybean in each year.

\begin{tabular}{|c|c|c|c|c|}
\hline Year & Rotation & $\mathrm{P}(\%)$ & $\mathrm{Fe}\left(\mathrm{mg} \mathrm{kg}^{1}\right)$ & $\mathrm{B}\left(\mathrm{mg} \mathrm{kg}^{1}\right)$ \\
\hline \multirow[t]{3}{*}{2006} & SSSS & $2.7 \mathrm{~b}$ & $54.3 \mathrm{~b}$ & $41.9 \mathrm{c}$ \\
\hline & $\mathrm{CSCS}$ & $4.1 \mathrm{a}$ & $87.5 \mathrm{a}$ & $61.5 \mathrm{a}$ \\
\hline & SSSS & $2.6 \mathrm{~b}$ & $54.0 \mathrm{~b}$ & $44.5 \mathrm{~b}$ \\
\hline \multirow[t]{3}{*}{2007} & SCSC & $4.1 \mathrm{a}$ & $91.8 \mathrm{a}$ & $59.5 \mathrm{~b}$ \\
\hline & $\mathrm{CCSC}$ & $4.5 \mathrm{a}$ & $92.8 \mathrm{a}$ & $75.3 \mathrm{a}$ \\
\hline & SSSS & $2.7 \mathrm{~b}$ & $54.0 \mathrm{~b}$ & $41.3 \mathrm{~b}$ \\
\hline \multirow[t]{3}{*}{2008} & CSCS & $5.1 \mathrm{a}$ & $99.3 \mathrm{a}$ & $66.8 \mathrm{a}$ \\
\hline & CCSS & $5.0 \mathrm{a}$ & $90.0 \mathrm{a}$ & $73.0 \mathrm{a}$ \\
\hline & SSCS & $5.6 \mathrm{a}$ & $71.5 \mathrm{a}$ & $70.0 \mathrm{a}$ \\
\hline
\end{tabular}

Notes: Means within a column in a given year followed by the same letter are not significantly different at $P \leq 5 \%$. Four replicates were used. Scheduled rotations were: SSSS = continuous soybean, CSCS $=1$ year corn followed by 1 year soybean followed by 1 year corn followed by 1 year corn, CCSS $=2$ years of corn followed by 2 years of soybean, SSCS $=2$ years of soybean followed by 1 year corn followed by 1 year soybean.

tion increases total protein, oil, and fatty acids. The consistent increase of seed oleic acid percentage represent a significant quality benefits for soybean seed as oleic acid is a desirable fatty acid for oil stability and long-shelf storage.

The change in protein, oil, and linoleic acid concentrations among years is likely due changes of growing season factors, especially temperature. Previous research showed that temperature affects protein and oil concentrations differently [25,29]. Soybean oil concentration increases as temperature increases up to a point, and then decreases with further temperature increases [30-32]. The contribution of temperature to total variability of seed composition was quantified and ranged from 19.4 to $28.6 \%$ for protein and from 4.5 to $6.9 \%$ for oil [25] for early planted soybeans grown in the Mid-South. Weather data [33] Table 5 showed that there were $5^{\circ} \mathrm{C}$ differences for maximum temperature and $3^{\circ} \mathrm{C}$ for average temperature between 2007 and 2008. These differences could be a source of inconsistency in seed composition across years [25]. Rainfall uniformity Table 6 could also be a source of inconsistency as indicted by differences in the seasonal or monthly total rainfall Table 6. Because of variability across years for seed composition and mineral nutrients, our approach was to focus mainly on comparing rotations with continuous soybean in each year separately to avoid variability across years.

The consistent increase of seed [Fe], [P], and [B] in all soybean-corn rotations than in continuous soybean, beginning second year of rotation could be due to greater $[\mathrm{Fe}],[\mathrm{P}]$, and $[\mathrm{B}]$ in soil as a result of the rotation, as indicated above. The relationships between nutrients in leaves and seed, and seed composition have been recently investigated. For example, application of B at V5 (vegetative) and R2 (full bloom), and combined (V5 + R2) stages resulted in a significant increase in protein and oleic acid [34].

Table 5. Maximum and average air temperature during the growing season in 2005 through 2008.

\begin{tabular}{|c|c|c|c|c|c|c|c|c|c|}
\hline \multicolumn{5}{|c|}{ Maximum air temperature $\left({ }^{\circ} \mathrm{C}\right)$} & \multicolumn{5}{|c|}{ Average air temperature $\left({ }^{\circ} \mathrm{C}\right)$} \\
\hline Month & 2005 & 2006 & 2007 & 2008 & Month & 2005 & 2006 & 2007 & 2008 \\
\hline Apr. & 24 & 27 & 23 & 23 & Apr. & 18 & 21 & 17 & 17 \\
\hline May & 28 & 29 & 30 & 28 & May & 22 & 23 & 24 & 22 \\
\hline Jun. & 32 & 33 & 33 & 33 & Jun. & 26 & 27 & 27 & 27 \\
\hline Jul. & 33 & 34 & 32 & 35 & Jul. & 28 & 28 & 27 & 28 \\
\hline Aug. & 35 & 36 & 37 & 32 & Aug. & 29 & 29 & 30 & 27 \\
\hline Sep. & 33 & 31 & 31 & 29 & Sep. & 26 & 23 & 26 & 24 \\
\hline Average & 31 & 32 & 31 & 30 & Average & 25 & 25 & 25 & 24 \\
\hline
\end{tabular}


Table 6. Rainfall (cm) during the growing season in 2005 through 2008.

\begin{tabular}{ccccc}
\hline Month & 2005 & 2006 & 2007 & 2008 \\
\hline Apr & 11.51 & 18.75 & 8.59 & 20.27 \\
May & 5.36 & 7.26 & 3.23 & 17.5 \\
Jun & 1.85 & 4.6 & 9.93 & 1.07 \\
Jul & 10.64 & 4.52 & 19.66 & 4.17 \\
Aug & 12.65 & 3.96 & 11.81 & 15.32 \\
Sep & 17.86 & 6.91 & 10.32 & 30.94 \\
Average & 9.98 & 7.67 & & 14.88 \\
\hline
\end{tabular}

\section{CONCLUSIONS}

The results showed that crop rotation increased yield by $22 \%$. Crop rotation increased seed protein, oil, and fatty acid production $\left(\mathrm{kg} \mathrm{ha}^{-1}\right)$ and seed [P], [Fe], and [B] and seed $\mathrm{P}, \mathrm{Fe}$, and $\mathrm{B}$ content $\left(\mathrm{g} \mathrm{ha}^{-1}\right)$, demonstrating the beneficial effects of crop rotation for soybean as opposed to a continuous cropping scheme. The consistent higher concentrations of $[\mathrm{P}],[\mathrm{Fe}]$, and $[\mathrm{B}]$, and oleic acid indicates the possible rotation benefits for higher seed mineral nutrition and composition qualities. Higher percentage of seed oleic fatty acid is a desirable trait for soybean industry because of its positive contribution to oil stability. Since commercial and public breeders are working to genetically modify soybean to produce increased oleic acid and decreased linolenic acid in the oil, this knowledge may help understand the results of breeding lines and help select target location to grow new value-added soybeans when they are released.

\section{ACKNOWLEDGEMENT}

We would like to thank Sandra Mosley for technical assistance and lab analysis. Also, we would like to thank Gary Shelton and Will Marlow for seed preparation and field management. We are also thankful to Debbie Boykin for statistical assistance. This research was funded by United States Department of Agriculture, Agricultural Research Service, project number 6402-21000-034-000.

\section{REFERENCES}

[1] Grieshop, C.M. and Fahey, G.C., Jr. (2001) Comparison of quality characteristics of soybeans from Brazil, China, and the United States. Journal of Agriculture and Food Chemistry, 49, 2669-2673.

[2] Wilson, R.F. (2004) Seed composition. In: Boerma, H. and Specht, J.E., Ed., Soybeans: Improvement, Production, and Uses, 3rd Edition, ASA, CSSA, and SSSA, Madison, 621-668.

[3] Cherry, J.H., Bishop, L., Hasegawa, P.M. and Heffler, H.R. (1985) Differences in the fatty acid composition of soybean seed produced in northern and southern areas of the U.S.A. Phytochemistry, 24, 237-241.

[4] Schnebly, S.R. and Fehr, W.R. (1993) Effect of years and planting dates on fatty acid composition of soybean genotypes. Crop Scince, 33, 716-719.

[5] Burton, J.W. Breeding soybeans for improved protein quantity and quality. In: Shibles, R., Ed., Proceedings of World Soybean Research Conference, III, Ames, IA, Westview Press, Boulder, 1984, pp. 361-367.

[6] Liu, K.S., Orthoefer, F. and Brown, E.A. (1995) Association of seed size with genotypic variation in the chemical constituents of soybeans. Journal of the American Oil Chemists' Society, 72, 189-192.

[7] Temperly, R.T. and Borges, R. (2006) Tillage and crop rotation impact on soybean grain yield and composition. Agronomy Journal, 98, 999-1004.

[8] Raimbault, B.A. and Vyn, T.J. (1991) Crop rotation and tillage effects on corn growth and soil structural stability. Agronomy Journal, 83, 979-985.

[9] Roder, W., Mason, S.C., Clegg, M.D. and Kniep, K.R. (1989) Crop root distribution as influenced by grain sorghum-soybean rotation and fertilization. Soil Science Society of American Journal, 53, 1464-1470.

[10] Copeland, P.J., Allmaras, R.R., Crookston, R.K. and Nelson, W.W. (1993) Corn-soybean rotation effects on soil water depletion. Agronomy Journal, 85, 203-210.

[11] Campbell, C.A. and Zentner, R.P. (1993) Soil organic matter as influenced by crop rotations and fertilization. Soil Science Society of American Journal, 57, 1034-1040.

[12] Karlen, D.L., Varvel, G.E., Bullock, D.G. and Cruse, R.M. (1994) Crop rotations for the 21st century. Advances in Agronomy, 53, 1-44.

[13] Crookston, R.K. and Kurle, J.E. (1989) Corn residue effect on the yield of corn and soybean grown in rotation. Agronomy Journal, 81, 229-232.

[14] Dabney, S.M., McGawley, E.C., Boethel, D.J. and Berger, D.A. (1988) Short-term crop rotation systems for soybean production. Agronomy Journal, 80, 197-204.

[15] Wilhelm, W.W. and Wortmann, C.S. (2004) Tillage and rotation interactions for corn and soybean grain yield as affected by precipitation and air temperature. Agronomy Journal, 96, 425-432.

[16] Bellaloui, N., Hanks, J.E., Fisher, D.K. and Mengistu, A. (2009a) Soybean seed composition is influenced by within-field variability in soil nutrients. Crop Management, doi:10.1094/CM-2009-1203-01-RS. 
[17] Bellaloui, N., Abbas, H.K., Gillen, A.M. and Abel, C.A. (2009b) Effect of glyphosate-boron application on seed composition and nitrogen metabolism in glyphosate-resistant soybean. Journal of Agriculture and Food Chemistry, 57, 9050-9056.

[18] Lohse, G. (1982) Microanalytical azomethine-H method for boron determination in plant tissue. Communications in Soil Science and Plant Analysis, 13, 127-134.

[19] John, M.K., Chuah, H.H. and Neufeld, J.H. (1975) Application of improved azomethine- $\mathrm{H}$ method to the determination of boron in soils and plants. Analytical Letters, 8, 559-568.

[20] Bandemer, S.L. and Schaible, P.J. (1944) Determination of iron. A study of the o-phenanthrolinemethod. Industrial and Engineering Chemistry Analytical Edition, 16, 317-319.

[21] Leoppert, R.L. and Inskeep, W.P. (1996) Colorimetric determination of ferrous iron and ferric iron by the 1,10-phenanthroline method. In: Bigham, J.M., Ed., Methods of Soil Analysis: Part 3. Chemical Methods, Soil Science Society of America, Madison, 659-661.

[22] Cavell, A.J. (1955) The colorimetric determination of phosphorus in plant materials. Journal of the Science of Food and Agriculture, 6, 479-480.

[23] Analytical Methods Committee (1959) Analyst, London, 84, 214.

[24] Bellaloui, N., Reddy, K.N., Zablotowicz, R.M. and Mengistu, A. (2006) Simulated glyphosate drift influences nitrate assimilation and nitrogen fixation in nonglyphosate-resistant soybean. Journal of Agriculture and Food Chemistry, 54, 3357-3364.

[25] Bellaloui, N., Smith, J.R., Ray, J.D. and Gillen, A.M. (2009c) Effect of maturity on seed composition in the early soybean production system as measured on nearisogenic soybean lines. Crop Science, 49, 608-620.

[26] AOAC (1990a) Method 988.05. In: Helrich, K., Ed., Official Methods of Analysis, 15th Edition, The Association of Official Analytical Chemists, Inc., Arlington.

[27] AOAC (1990b) Method 920.39. In: Helrich, K., Ed., Official Methods of Analysis, 15th Edition, The Association of Official Analytical Chemists, Inc., Arlington.

[28] SAS (2001) SAS 9.1 TS level 1M3, Windows version.5.1.2600, SAS Institute, Gary.

[29] Piper, E.L. and Boote, K.J. (1999) Temperature and cultivar effects on soybean seed oil and protein concentrations. Journal of the American Oil Chemists' Society, 76, 1233-1242.

[30] Gibson, L.R. and Mullen, R.E. (1996) Soybean seed quality reductions by high day and night temperature. Crop Science, 36, 1615-1619.

[31] Dornbos, D.L. and Mullen, R.E. (1992) Soybean seed protein and oil contents and fatty-acid composition adjustments by drought and temperature. Journal of the American Oil Chemists' Society, 69, 228-231.

[32] Thomas, J.M.G., Boote, K.J., Allen, L.H., Jr., GalloMeagher, M. and Davis, J.M. (2003) Seed physiology and metabolism: Elevated temperature and carbon dioxide effects on soybean seed composition and transcript abundance. Crop Science, 43, 1548-1557.

[33] Delta Research and Extension Center. http://www.deltaweather.msstate.edu/

[34] Bellaloui, N., Reddy, K.N., Gillen, A.M. and Abel, C.A. (2010) Nitrogen metabolism and seed composition as influenced by foliar boron application in soybean. Plant and Soil, 54, 3357-3364. 